\title{
Analysis of Palm Fiber and Coconut Coir Usage as Purse Seine Cargo Chamber Insulator
}

\author{
Alam Baheramsyah ${ }^{1}$, Ede Mehta Wardhana ${ }^{2}$, Muhammad Azis Husein ${ }^{3}$
}

\begin{abstract}
Indonesia's annual marine fish potential of 6.5 million tons is spread over the waters of Indonesia's Exclusive Economic Zone. The constraint of which are often faced by fishermen is the decay that occurs during the storage process in which the fish becomes less fresh when it comes to the fish auction. The decomposition rate of fish after fishing is strongly influenced by fishing techniques, handling techniques, and onboard storage. The cooling or freezing process is the best method chosen for handling the catched fish to maintain its quality and freshness. This study was conducted by modifying the insulation material of purse seine cargo hold using a coolbox made of insulated materials from coconut coir and Palm Fiber. The purpose of this study is to know the influence of coconut coir and Palm Fiber composite insulation to temperature and cooling time in which will be compared with styrofoam insulated coolbox. The study was conducted by testing some specimens which will be selected with the thermal conductivity and lowest density. The compositions which is chosen were coconut coir and Palm Fiber composite that is mixed with polyurethane glue 4:4:1 ratio, having a thermal conductivity of $0.4643 \mathrm{~W} / \mathrm{mK}$ and a density of $0.18 \mathrm{~g} / \mathrm{cm}^{3}$. Coolbox's test using coconut coir and Palm Fiber composite insulation was done using a 400 gram fish as a cooling load and ice that had been destroyed weighing 2 kilograms as a cooling source. Coolbox with coconut coir and Palm Fiber composite insulation has the lowest fish temperature of $0.7^{\circ} \mathrm{C}$ while the coolbox with styrofoam insulation has the lowest fish temperature of $1.8^{\circ} \mathrm{C}$. In addition, coconut coir and Palm Fiber composite coolbox is able to keep temperature below $20^{\circ} \mathrm{C}$ for 16,5 hours, while with the same treatment styrofoam insulated coolbox is only able to keep the temperature below $20^{\circ} \mathrm{C}$ for 16 hours. So it can be concluded the use of coconut coir and Palm Fiber composite is effective as insulation material because it can offset the performance of the insulation styrofoam.
\end{abstract}

Keywords_Coconut Coir, Palm Fiber, Polyurethane, PVAc, Insulation, Coolbox, Styrofoam

\section{Introduction ${ }^{1}$}

$\mathrm{T}_{\mathrm{h}}$ he Indonesian Exclusive Economic Zone

(ZEEI), which is divided into nine major marine areas, has the potential marine fish of 6.5 million tons per year $[22,24]$. Constraints that often faced by fisherman is to keep freshness of fish. The decomposition rate of fish is strongly influenced by fishing techniques, handling techniques, and onboard storage [21, 25, 30, 31] Marine products are easier to decompose than other high-protein products $[1,3,12]$. There were because of; some seafood products contain high levels of osmoregulation in the form of non-protein nitrogen such as trimethylamine, urea, amino acids and so on which is a good medium for bacterial growth; marine products which were harvested from cold water contain bacterial flora that is not easily inhibited by cold temperature treatment than animal or plant flora by Susanti et al [27].

The best method chosen is the process of cooling or freezing to maintain the quality and freshness of the fish in storage. There are three ways to maintain the freshness of the fish with ice, with cold air (refrigeration), and with cold water (chiller) by Ilyas et al [12]. For large fishing vessels and modern, the cooling process is using a

\footnotetext{
1) Alam Baheramsyah, Department of Marine Engineering, Sepuluh Nopember Institute of Technology, Surabaya 60111, Indonesia, Email : abaheramsyah@gmail.com

2) Ede Mehta Wardhana, Department of Marine Engineering, Sepuluh Nopember Institute of Technology, Surabaya 60111, Indonesia, Email : ede@ne.its.ac.id

3) Muhammad Azis Husein, Department of Marine Engineering, Sepuluh Nopember Institute of Technology, Surabaya 60111, Indonesia, Email : azis.husein@gmail.com
}

cooling machine that adopts a vapor compression system [4]. While the traditional way, the ice cubes are transported into the fishing boat's cargo chamber before the vessel sails with the addition of salt to keep the ice melting point higher, it is still practiced mainly for small and medium fishing vessels [26].

There are many fish cooler in the market that using synthetic raw materials because it is easy in the process of making. Synthetic materials have ability to maintain temperature of the fish cooler to keep it low, but the raw materials of synthetic chemicals such as polyethylene and fiberglass have a high enough price that increases the cost of making fish ship cargo chamber. Benefits of having a great insulation cargo chamber by Hidayat are: [10]

a. Conserve ice usage

b. Reduce the risk of decay

c. Expand the fishing area

d. Expand your marketing reach

e. Reduce depreciation of the catch

f. Increase fisherman's income

g. Delaying the sale time to get a reasonable price

Innovations that can be done is to provide a natural fiber insulator on the wall of the loading room [28]. This study will use Palm Fibers and coconut coir as a cheap insulator and easy to obtain by using polyurethane glue or PVAc glue as adhesive. This study is done by creating an insulated cool box from both natural materials as shown in Figure 1. The use of natural fiber insulator is expected to minimize the heat transfer and can maintain a low temperature and keep the freshness of the fish up to the place of sale. In order to be able to conduct a smoothly and well-directed study then it takes some limitations of the problem, such as:

a. Palm Fiber and coconut coir insulation using lamination technique

b. Not analyzing the chemical content in the insulation material 


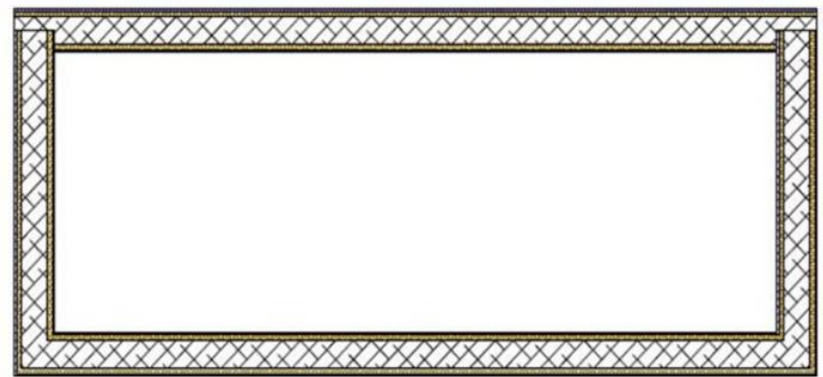

Figure 1. Ilustrate insulation of coolbox

c. The specified composite characteristics are the density and thermal conductivity of Palm Fiber and coconut coir composites.

Palm Fibers are natural fibers derived from the Arena tree or the Latin name is Arenga pinnata [29]. Fiber has many advantages such as Durable up to hundreds or even thousands of years more because it has a strong fiber; Resistant to acid and sea salt; Prevents penetration of soil termites by Ishak [14]. There is a research by Yunita [29] and the conclusion is the thermal conductivity value of foamed concrete with the addition of Arenga Pinnata Merr fiber has the lowest value in the specific gravity of 1.4 with $2.0 \%$ fiber percentage of $0.43 \mathrm{~W} / \mathrm{m}^{\circ} \mathrm{C}$.

Other natural fibers are coconut coir $[15,19]$. Coir is a part of mesocarp (blanket) in the form of coarse fibers of coconut skin $[2,6,7]$. The addition of coconut coir to the composite mixture can be optimally done up to $30 \%$ with a composite thermal conductivity of $0.05 \mathrm{~W} / \mathrm{m}^{\circ} \mathrm{C}$. The composite mixture has the capability of maintaining $3 \mathrm{~kg}$ of ice tube at $5^{\circ} \mathrm{C}$ inside the hold for 14 hours, below $10{ }^{\circ} \mathrm{C}$ for 39 hours and melting ice for 40.45 hours at $13.7^{\circ} \mathrm{C}$ by Polaris [19].

A purse seine is a tool used to catch small pelagic fish that form hordes [4,5]. According to the book "Fishing Methode" by Ayodhyoa [4] in the journal "Analysis of Traditional Fish Investments Purseiner 30 GT" by Mulyatno [18], fish targeted for purse seine fishing are "pelagic shoaling species" which means the fish form gangs with high density and are near the water surface.

Polyurethanes are a solid plastic froth mixture of Polyol and Isocyanate solution (1: 1 scale) commonly used as a heat insulator material in the storage area $[8,9,20]$. This material is commonly used as a temperature-retaining insulation on fish storage holds by Nasution [20]. The process of solid polyurethane expansion through four stages: Mixing solution; Stirring; Expands; Compaction

In the journal by Masturi [17] states that PVAc is a polymer that has a very strong viscosity properties that are often used as the basic ingredients of glue manufacture. cloth, paper, and wood. PVAc has odorless, non-flammable, and faster solid properties stated by Purnama [23]. In addition, PVAc is also widely used as a matrix on the manufacture of composite materials thus increasing the strength of the material. Objective of this research is to find the best materials available for the insulation of the coolbox, and compare it with the coolbox that is available in the market.

\section{METHOD}

\subsection{Specimen Creation}

The material used is Palm Fiber (Arenga pinnata) and coconut coir as a base material by using adhesive in the form of Aliphatic PVAC or Polyurethane glue. Before mixing the ingredients, some preparations are made on the main ingredients, such as.:

1.1 Prepare Palm Fiber.

1.2 Prepare coconut coir.

3.3 Determination of the number of fibers for comparison.

For Palm Fiber with volume $80 \mathrm{~cm}^{3}$ is 15 (fifteen) grams, while for coconut coir weight with volume and same percentage is 10 (ten) gram. There are two types of adhesive in the specimens creation process, that are using Polyurethane glue and Aliphatic PVAc glue. Three different variations of specimens will be made of the fiber ratio for each type of adhesive glue, so that the final result is six specimens. The variations are:

- Using Polyurethane Adhesives:

a) Specimens 1=70\% coconut coir: $30 \%$ fiber fibers $(5.6: 2.4: 1)$

b) Specimen $2=50 \%$ coconut coir: $50 \%$ fiber fibers $(4: 4: 1)$

c) Specimens $3=30 \%$ coconut coir: $70 \%$ fiber fibers $(2.4: 5.6: 1)$

- Using Polyvinyl acetate (PVAc) adhesive

d) Specimens $4=70 \%$ coconut coir: $30 \%$ fiber fibers (5.6: $2.4: 1)$

e) Specimens 5=50\% coconut coir: $50 \%$ fiber fibers (4: 4: 1)

f) Specimens $6=30 \%$ coconut coir: $70 \%$ fiber fibers $(2.4: 5.6: 1)$

2.1.(1) Specimen for Density Test

Specimens to be made for the type of mass test have a predetermined size of dimensions $\mathrm{p} \times 1 \times \mathrm{t}$ (50 $\mathrm{mm} \times 50 \mathrm{~mm} \times 20 \mathrm{~mm}$ ). The variation of making specimens for the measurement of density are:

- Using $5 \mathrm{ml}$ Polyurethane adhesives (4.5gr):

a) Specimen $1(7: 3: 1)$

$35 \mathrm{~mL}$ coconut coir: $15 \mathrm{~mL}$ Palm Fibers : $5 \mathrm{~mL}$ $\mathrm{PU}$

b) Specimen $2(5: 5: 1)$

$25 \mathrm{~mL}$ coconut coir: $25 \mathrm{~mL}$ Palm Fibers : $5 \mathrm{~mL}$ PU

c) Specimen $3(3: 7: 1)$

$15 \mathrm{~mL}$ coconut coir : $35 \mathrm{~mL}$ Palm Fibers: $5 \mathrm{~mL}$ PU

Using 10ml (11gr) Polyvinyl acetate (PVAc) adhesives: 
d) Specimen $4(7: 3: 2)$

$35 \mathrm{~mL}$ coconut coir : $15 \mathrm{~mL}$ Palm Fibers : $10 \mathrm{~mL}$ (PVAc)

e) Specimen $5(5: 5: 2)$

$25 \mathrm{~mL}$ coconut coir : $25 \mathrm{~mL}$ Palm Fibers : $10 \mathrm{~mL}$ (PVAc)

f) Specimen $6(3: 7: 2)$

$15 \mathrm{~mL}$ coconut coir : $35 \mathrm{~mL}$ Palm Fibers : $10 \mathrm{~mL}$ (PVAc) maintaining cooling temperature and the effective cooling time between the first coolbox using Palm Fiber and coconut coir insulated and the second coolbox which is insulated styrofoam.

\section{RESULTS AND DISCUSSION}

\subsection{The result of specimen manufacture}

The trials of adhesives were performed 3 times using Polyurethane glue of $30 \mathrm{~mL}, 20 \mathrm{~mL}$, and $10 \mathrm{~mL}$.

TABLE 1.

DENSITY SPECIMEN

\begin{tabular}{cccc}
\hline No. Specimen & Mass (gram) & Volume $\left(\mathrm{cm}^{3}\right)$ & Density $\left(\mathrm{gr} / \mathrm{cm}^{3}\right)$ \\
\hline 1 & 8 & 50 & 0.16 \\
2 & 9 & 50 & 0.18 \\
3 & 9 & 50 & 0.18 \\
4 & 12 & 50 & 0.24 \\
5 & 12 & 50 & 0.24 \\
6 & 13 & 50 & 0.26 \\
\hline
\end{tabular}

\section{1.(2) Specimen for Thermal Conductivity Tests}

Specimens to be made for the thermal conductivity test have a predetermined size that is cylindrical diameter measuring $46 \mathrm{~mm}$ with a height of $50 \mathrm{~mm}$. The variation of making specimens for the measurement of thermal conductivity are:

- Using 10ml (9 gr) Polyurethane adhesive:

a) Specimen $1(28: 12: 5)$

$56 \mathrm{~mL}$ coconut coir : $24 \mathrm{~mL}$ Palm Fibers: 10 $\mathrm{mL}$ PU

b) Specimen $2(4: 4: 1)$

40 mL coconut coir: 40 mL Palm Fibers: 10 $\mathrm{mL}$ PU

c) Specimen $3(12: 28: 5)$

24 mL coconut coir: 56 mL Palm Fibers: 10 $\mathrm{mL} \mathrm{PU}$

- Using Polyvinyl acetate (PVAc) adhesive as much as $20 \mathrm{ml}(22 \mathrm{~g})$ :

d) Specimen $4(14: 6: 5)$

$56 \mathrm{~mL}$ coconut husk: $24 \mathrm{~mL}$ fiber fibers: 20 $\mathrm{mL}$ (PVAc)

e) Specimen $5(2: 2: 1)$

$40 \mathrm{~mL}$ coconut husk: $40 \mathrm{~mL}$ fiber fibers: 20 $\mathrm{mL}$ (PVAc)

f) Specimen $6(6: 14: 5)$

$24 \mathrm{~mL}$ coconut husk: $56 \mathrm{~mL}$ fiber fibers: 20 $\mathrm{mL}$ (PVAc)

\subsection{Specimen testing}

(1) Density Tests

(2) Thermal Conductivity Tests

\subsection{Coolbox design}

(1) Selection of Insulating Fibers

(2) Coolbox Making

\subsection{Coolbox Testing}

Coolbox's insulation testing materials using wet ice that measured with a digital thermometer to determine the temperature for 24 hours. Coolboxes are tested in
The ideal use was $10 \mathrm{~mL}$. The advantages obtained from the use of polyurethane adhesive are: a short drying process with a temporary drying time duration of 2 minutes and can be removed from the mold; the expanded polyurethane properties can fill the gap between the fibers making the binding of the specimen stronger. For specimens of $45-50 \mathrm{~mm}$ in diameter with a height of $50 \mathrm{~mm}$ it takes 20 minutes to completely dry and put no need to be exposed to direct sunlight.

But the disadvantage of polyurethane adhesives is the need for high caution because the glue is so easy to dry; adhesive strength is very strong so it makes it difficult when exposed to skin directly; requires low humidity so the glue does not expand too much.

The advantages derived from the use of Aliphatic PVAc adhesive are: the ease of formation due to longer drying time; because the drying time is relatively long mixing process between adhesive glue with fiber can be more evenly; a base material consisting of water so that it is easy to clean when exposed to the skin directly.

But the weakness of Aliphatic PVAc adhesive is it takes a long time in the drying process because the base material is water that makes the glue dries longer. For a specimen $45-50 \mathrm{~mm}$ in diameter with a height of $50 \mathrm{~mm}$ it takes 3 days to dry perfectly and put in the room open and exposed to direct sunlight to speed up the drying process of the specimen.

3.1.(1) Specimens for Density Tests.

3.1.(2) Specimens for Thermal Conductivity Tests

Using polyurethane, for specimens of dimension $50 \mathrm{~mm} \times 50 \mathrm{~mm} \times 20 \mathrm{~mm}$ it takes 20 minutes to completely dry and put no need to be exposed to direct sunlight. Meanwhile using PVAc, for specimens of dimension $50 \mathrm{~mm} \times 50 \mathrm{~mm} \times 20 \mathrm{~mm}$ di it takes 3 days to dry completely and put in open space and exposed to direct sunlight to speed up the drying process of the specimen.

\subsection{Specimen Test Results}

From the data collection of specimen test results, we 
will determine the exact composition of insulating material with the lowest thermal conductivity and the lightest density for use at the design stage of the tool.

\section{2.(2) Thermal Conductivity Tests Results}

The test was conducted for 3 days with the number of tests that is 2 specimens/day starting from 22-25 April 2018. The test equipment along with the test material

TABLE 2.

THERMAL CONDUCTIVITY SPECIMEN

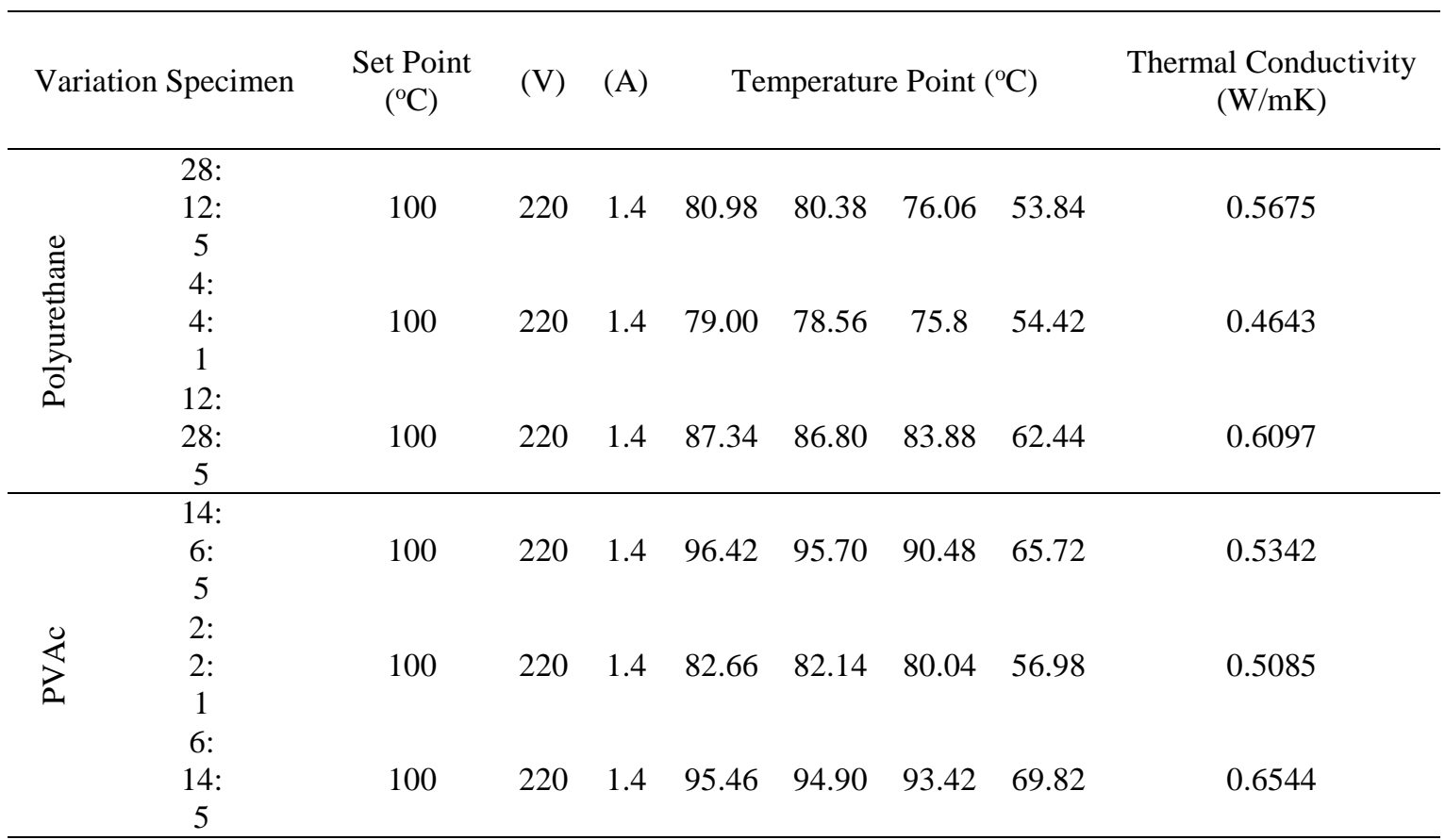

\section{2.(1) Density Test Result}

The result of the density test as shown in Table $\mathbf{1}$. Based on the calculation of the density of the specimen obtained, it can be seen that by using polyurethane adhesive specimen with the lowest density is specimen 1 with composition $70 \%$ coconut coir: $30 \%$ Palm Fiber that is $0.16 \mathrm{gr} / \mathrm{cm}^{3}$, while specimen 2 with composition 50\% coconut coir : 50\% Palm Fibers and 3 specimens with $30 \%$ coconut coir and $70 \%$ Palm Fibers having the same density of $0.18 \mathrm{gr} / \mathrm{cm}^{3}$. While the density using Polyvinyl acetate (PVAc) glue adhesive, the specimen with the lowest density are specimen 4 with $70 \%$ coconut coir : $30 \%$ Palm Fibers composition and specimen 5 with $50 \%$ coconut coir and 50\% Palm Fiber composition of $0.24 \mathrm{gr} / \mathrm{cm}^{3}$. Specimens 6 with $30 \%$ coconut coir composition and $70 \%$ Palm Fiber have the largest density of $0.26 \mathrm{~g} / \mathrm{cm}^{3}$. will experience heating for 120 minutes to make the temperature of the test specimen to be stable and not change significantly. 5 data retrieval with 5 -minute pause so the total time required for testing a specimen is 140 minutes.

After data collected through thermal conductivity testing, the data is processed to obtain the result of the thermal conductivity value of each specimen. The result are shown in Table 2. The principle of calculating the value of thermal conductivity is to use the conductivity ratio of the heating metal used to heat the specimen $[11,13,16]$. This test apparatus uses pure copper metals for heating metals and the thermal conductivity values used as a reference are derived from the book "Fundamental of Heat and Mass Transfer (Sixth Edition)" by Incropera [13].

Based on the experiment, it can be seen that by using Polyurethane glue adhesive which has the lowest thermal 
TABLE 3 .

SELECTION OF COMPOSITE COMPOSITION

\begin{tabular}{|c|c|c|c|c|c|c|c|c|}
\hline \multirow{2}{*}{\multicolumn{2}{|c|}{ No. Specimen }} & \multicolumn{2}{|c|}{ Thermal Conductivity } & \multicolumn{2}{|c|}{ Density } & \multicolumn{2}{|c|}{ Easy to Make } & \multirow{2}{*}{ Total Score } \\
\hline & & Rank & Score & Rank & Score & Rank & Score & \\
\hline \multirow{3}{*}{$\begin{array}{l}\frac{1}{0} \\
\frac{1}{2} \\
0 \\
\vdots \\
0 \\
0\end{array}$} & $1(28: 12: 5)$ & 4 & 0.25 & 1 & 0.3 & 2 & 0.166 & $71.6 \%$ \\
\hline & $\begin{array}{c}2 \\
(4: 4: 1)\end{array}$ & 1 & 0.5 & 2 & 0.249 & 1 & 0.2 & $94.9 \%$ \\
\hline & $\begin{array}{c}3 \\
(12: 28: 5)\end{array}$ & 5 & 0.165 & 2 & 0.249 & 3 & 0.134 & $54.8 \%$ \\
\hline \multirow{3}{*}{ 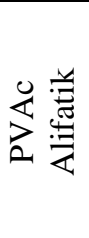 } & $\begin{array}{c}4 \\
(14: 6: 5)\end{array}$ & 3 & 0.335 & 3 & 0.201 & 5 & 0.066 & $60.2 \%$ \\
\hline & $\begin{array}{c}5 \\
(2: 2: 1)\end{array}$ & 2 & 0.415 & 3 & 0.201 & 4 & 0.1 & $71.6 \%$ \\
\hline & $\begin{array}{c}6 \\
(6: 14: 5)\end{array}$ & 6 & 0.0835 & 4 & 0.15 & 6 & 0.0334 & $26.7 \%$ \\
\hline
\end{tabular}

conductivity value is specimen 2 with the ratio of $4: 4: 1$ (coconut fiber: Palm Fiber: polyurethane) of $0.4643 \mathrm{~W} /$ $\mathrm{mK}$. The next is a specimen 1 with a composition ratio of 28: 12: 5 (coconut fiber: Palm Fibers: polyurethane) of $0.5675 \mathrm{~W} / \mathrm{mK}$ and specimen 3 with a composition ratio of 12: 28: 5 (coconut fiber: Palm Fibers: polyurethane) of $0.6097 \mathrm{~W} / \mathrm{mK}$. While the calculation of thermal conductivity by using Polyvinyl acetate glue adhesive (PVAc), the specimen which has the lowest thermal conductivity is specimen 5 with the composition ratio of 2: 2: 1 (coconut fiber: Palm Fibers: Polyvinyl acetate) that is $0.5085 \mathrm{~W} / \mathrm{mK}$. The next is 4 specimen with a ratio of 14: 6: 5 (coconut fiber: Palm Fiber: Polyvinyl acetate) of $0.5342 \mathrm{~W} / \mathrm{mK}$ and specimen 6 with a composition ratio of 6: 14: 5 (coconut fiber: Palm Fibers: Polyvinyl acetate) that is equal to $0.6544 \mathrm{~W} / \mathrm{mK}$.

\subsection{Selection of Composite Compositions}

Based on the results of the assessment that has been done in Table 3, determined that the composition of fiber and adhesive used is specimen number 2 . This is because it has the highest score with a value of $94.9 \%$. This specimen use polyurethane adhesive glue with a composition ratio of 28: 12: 5 (coconut coir: Palm Fibers: polyurethane).

\subsection{Coolbox Testing}

The testing process is carried out by simultaneous testing of time, location, cooling load, cooling, and testing methods.

Coolboxes are treated with several terms of condition. Here are some of the treatments given to the coolbox:

3.4.(1) The test is done in front of Marine Machinery System Laboratory, Department of Shipping System Engineering, Marine Technology Faculty, Sepuluh Nopember Institute of Technology.

3.4.(2) Testing is done for 24 hours at the same time starting from Saturday, July 7, 2018 at $20.00 \mathrm{pm}$ until Sunday 8 July 2018 at 20.00 pm.
3.4.(3) Temperature data collection is done simultaneously every 30 minutes.

3.4.(4) On the coolbox cover is given the prevention of air or temperature leakage using a black ducktape which is given around the coolbox cover.

3.4.(5) The test is performed using four thermometers placed at the same measurement point, namely:

a) at the base of the coolbox;

b) on the inside of the fish cooling load;

c) on free air in coolbox;

d) on the environment around coolbox.

3.4.(6) Using the same type of ice and fish, using fractioned ice and a tuna fish.

3.4.(7) Using the same comparison between fish and ice, by a ratio of 1: 5 . One cob weighing 400 grams and 2000 gram of ice shards.

3.4.(8) When placing an ice and fish as cooling load is treated the same, there is 1000 grams of ice in the base of the coolbox, then given a cooling load of fish, then given ice back on the body of fish as much as 1000 grams.

There are six cool box testing as shown on Figure 2 . Types of insulation used in the coolbox from left to right are: styrofoam insulation, composite insulation of corncobs and polyurethane, mahogany and kapok insulation, composite insulation of sengon sawdust and straw, composite insulation of coconut coir and Palm Fibers, and the last is insulation of bamboo sawdust and resin. Styrofoam insulation coolbox is using for comparison the other insulation coolbox.

\subsection{Analysis of Test Results}

There are three variant types data based on the number of measured temperature points. The data is processed and inserted into the graph to see the difference clearly between the two different types of insulated coolbox. According to Diyantoro, 2007 in Sitakar, et al., [25] fish can still survive 1-2 days when in temperatures below $15^{\circ} \mathrm{C}-20^{\circ} \mathrm{C}$. 


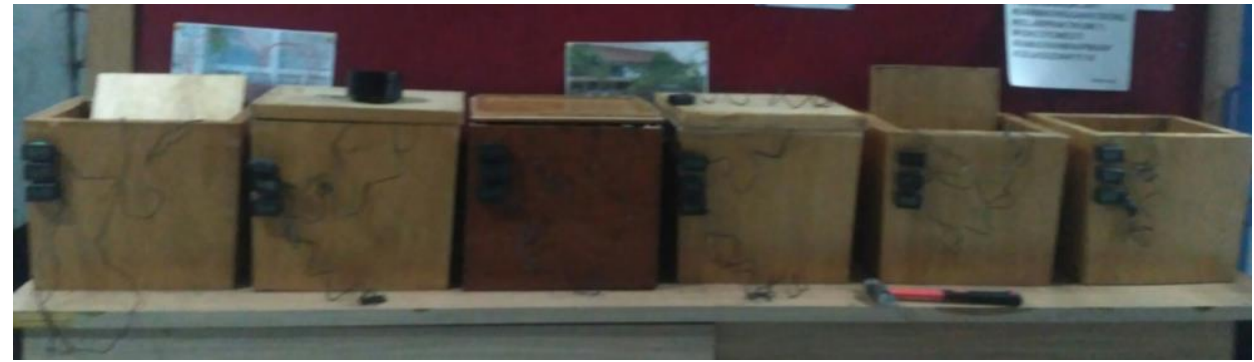

Figure 2. Coolbox testing process

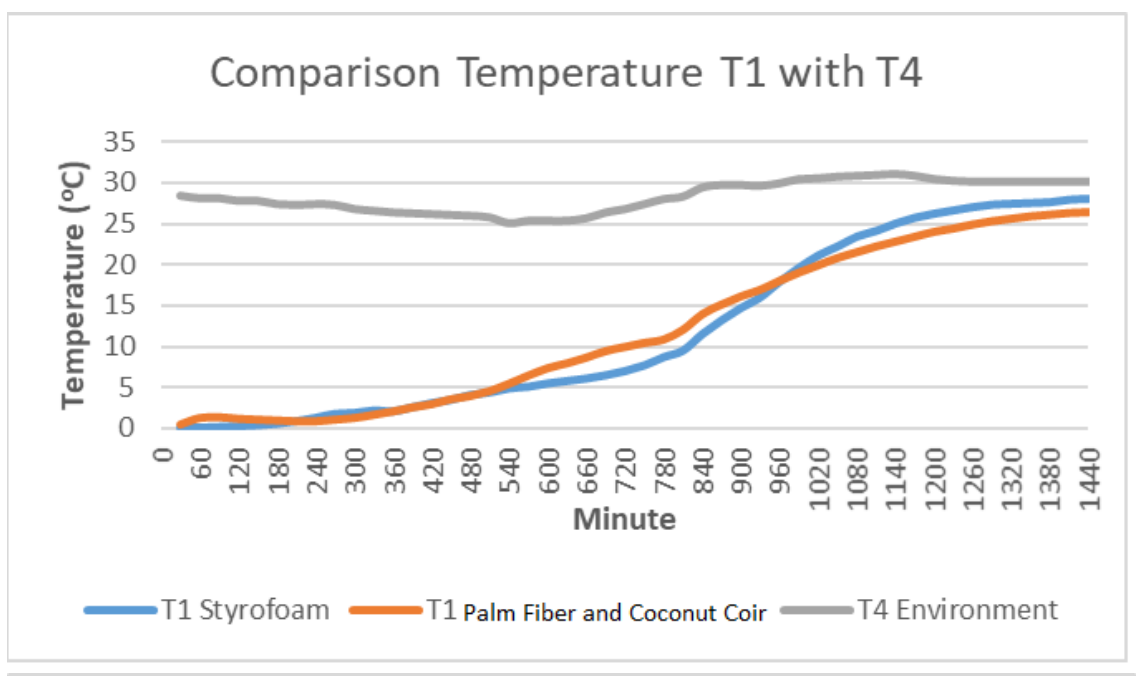

It is therefore give

Figure 3. Comparison coolbox's base with environment temperature graph

$15^{\circ} \mathrm{C}$ in the cooli effectiveness of insula 3.5.(1) Comparison Environmental Te The result of temperature witl shown in Figt temperature point 30 minutes of $\mathrm{t}$ ] measured on coo coir and Palm F insulated styrofoa the ambient temps

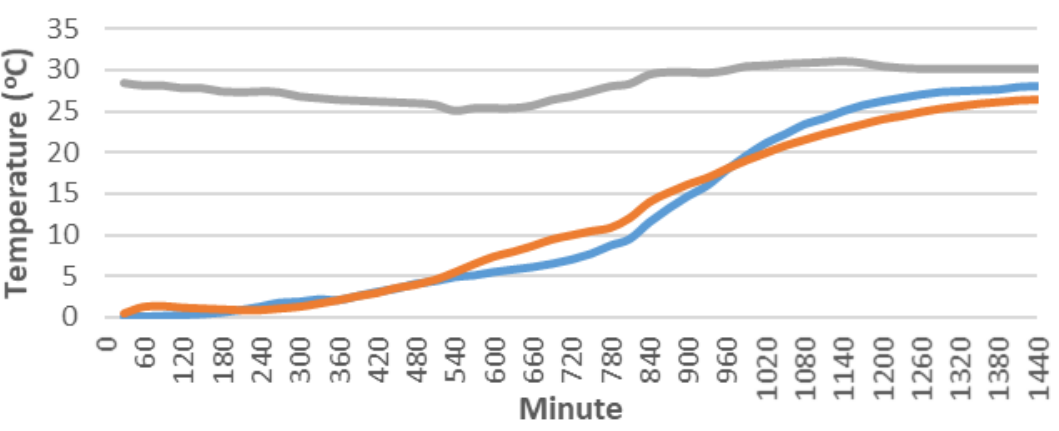

T1 Styrofoam T1 Coconut Coir+ljuk Fiber —T4 Environment
${ }^{\circ} \mathrm{C}$ obtained on

rature with

environment is the freshness of $20{ }^{\circ} \mathrm{C}$ cause the jing fish meat. e the effect of in fish meat in

environmental owest measured :d coconut coir
The lowest and longest point in maintaining the measured temperature on the T1 coolbox insulated composite coco fiber and fibers fibers obtained at the data collection process to 7 and 8 of $0.9^{\circ} \mathrm{C}$ with time for 30 minutes and environmental temperature of $27.3^{\circ} \mathrm{C}-27.4^{\circ} \mathrm{C}$, whereas in the insulated coolbox The lowest and longest temperature styrofoam measured at $\mathrm{T} 1$ is $0.1^{\circ} \mathrm{C}$ for 30 minutes and an and Palm Fiber composite of $0.7^{\circ} \mathrm{C}$ when the ambient temperature of $27.4^{\circ} \mathrm{C}$. While the lowest temperature measured at point $\mathrm{T} 2$ coolbox insulated styrofoam is $1.8^{\circ} \mathrm{C}$ with an ambient temperature of $28^{\circ} \mathrm{C}$. This lowest point is also the lowest and longest temperature point due to the constantly changing temperatures in every data retrieval. 


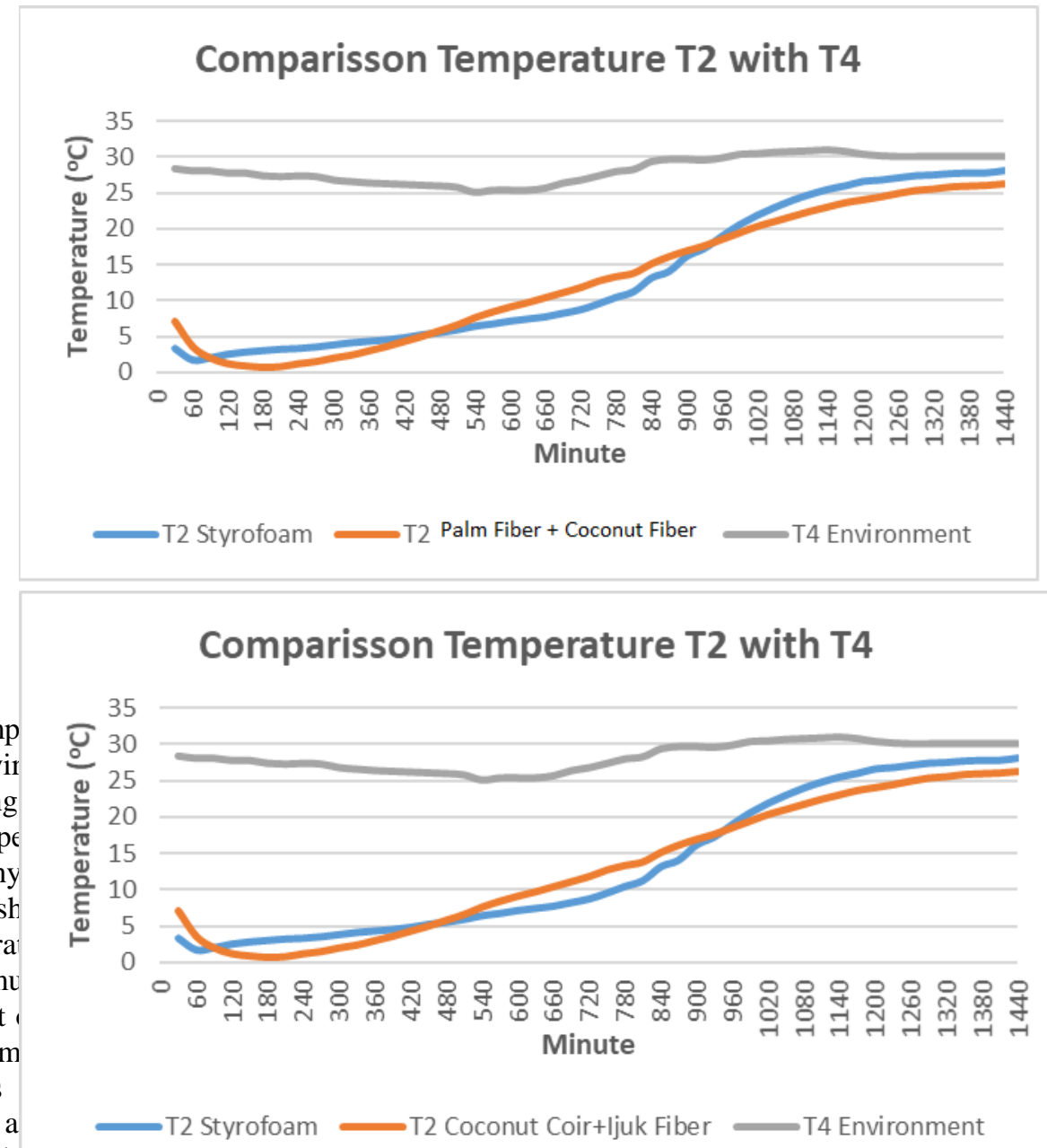

e coolbox, a final

3.5.(3) Comp

with Envir

Comparing

ambient tempe contains many quality of fish warm tempera in the air to mı

The result , with environm Temperatures coconut coir a minutes until

T2 Styrofoam $\longrightarrow$ T2 Coconut Coir+ljuk Fiber $\longrightarrow$ T4 Environment conut fiber insulation lue adhesive has a 4 iber: fiber fibers: inal analyzes that can

erature is $25.1^{\circ} \mathrm{C}$ and average ambient ing is $28.3^{\circ} \mathrm{C}$.

a coolbox is: $\mathrm{T} 1=$ $23.14^{\circ} \mathrm{C}$ while for alm Fiber composite $\Gamma 2=12.98^{\circ} \mathrm{C}, \mathrm{T} 3=$

environmental temperature of $26.4^{\circ} \mathrm{C}-26.8^{\circ} \mathrm{C}$, while in the coolbox insulated styrofoam obtained at minute 60 to minute 690 with a total time of 10.5 hours. The recorded environmental temperature of $26.4^{\circ} \mathrm{C}-27.8^{\circ} \mathrm{C}$. Until the end, free air temperature testing in coconut coir and Palm c) Based on the tests performed, the durability of styrofoam coolbox in maintaining the fish temperature below $20^{\circ} \mathrm{C}$ is for 930 minutes or 15 hours 30 minutes, while the resilience of coconut coir and Palm Fibers composite coolbox in

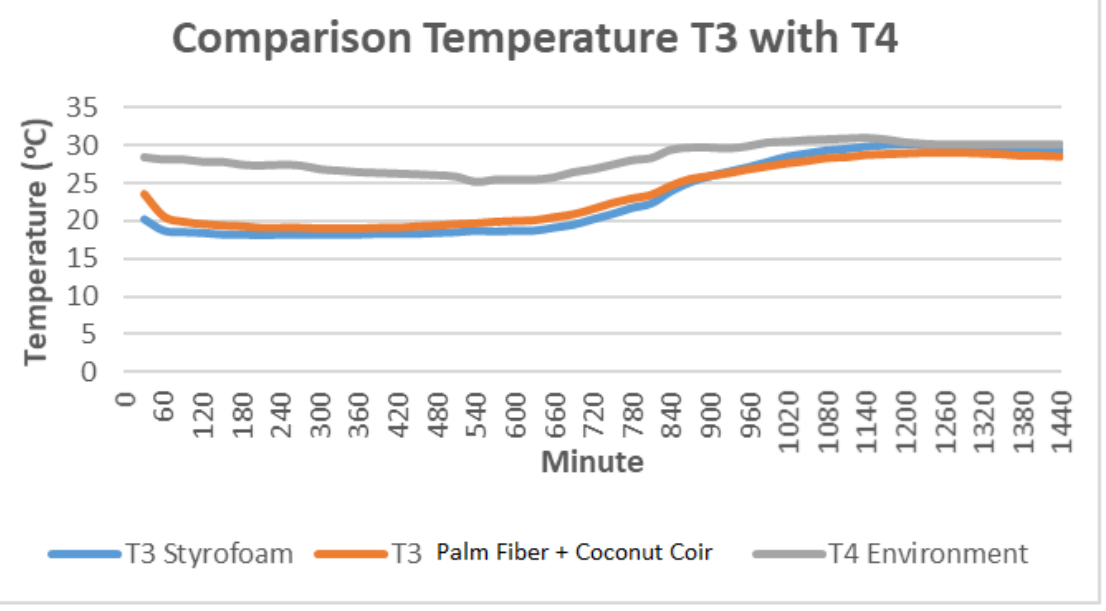

Figure 5. Comparison air in the coolbox with environment temperature graph

Fiber composite coolbox's are lower than free-air temperatures in styrofoam coolbox and parallel to the ambient temperature.

3.6 Final Analysis

After performing a comparison of various maintaining fish temperature below $20^{\circ} \mathrm{C}$ is for 960 minutes or 16 hours.

d) Coconut coir has a thermal conductivity value of 0.05 $\mathrm{W} / \mathrm{mK}$ and Palm Fiber thermal conductivity below $0.5 \mathrm{~W} / \mathrm{mK}$. The utilization of coconut coir and Palm Fibers is still limited for simple purposes so the 
price is still fairly cheap. Affordable prices and abundant availability of materials cause coconut coir and Palm Fibers to be an alternative to industrial activities in the heat insulation field because of their low thermal conductivity.

e) The best composite composition of coconut coir and Palm Fibers is the ratio of 4 parts of coconut coir: 4 parts of Palm Fibers: 1 part of polyurethane glue which yields a thermal conductivity value of 0.4643 $\mathrm{W} / \mathrm{mK}$.

f) The coolbox weight that has been made with coconut coir insulation and Palm Fibers is 2260 grams, while the weight of the styrofoam insulated coolbox weight 1643 grams. The use of styrofoam insulated coolbox is more advantageous because it can reduce a dead load of ships when used to store fish catch.

g) Insulation material needed to make 1 piece composite coolbox is a 4-liter mixture with composition 312.5gram coconut coir for Rp4.687,00: 312,5 gr Palm Fiber for Rp6.250,00: 400 gr polyurethane glue for Rp40.000,00 and a total cost of Rp 50.937,00. This is certainly more expensive than the mass-produced styrofoam insulation to suppress the production load with the same size for Rp 35,000.00.

h) In addition, the solution that can be done is the use of the forging system in the manufacture of the composite board. The system uses heat-hardened methods and uses hot steam injection to raise the temperature and make the adhesive stronger. By using heat-hardened systems, production can be increased as the manufacture of composite boards will be en masse.

\section{CONCLUSION}

From the study that I make, can be taken some conclusions and suggestions, there are:

4.1 The results of the calculation of the density and thermal conductivity for specimens 1 to 6 respectively yield values of $\left(0.16 \mathrm{gr} / \mathrm{cm}^{3} ; 0.5675\right.$ $\mathrm{W} / \mathrm{mK}),\left(0.18 \mathrm{gr} / \mathrm{cm}^{3} ; 0.4643 \mathrm{~W} / \mathrm{mK}\right),\left(0.18 \mathrm{gr} / \mathrm{cm}^{3}\right.$; $\left(0.24 \mathrm{gr} / \mathrm{cm}^{3} ; 0.5342 \mathrm{~W} / \mathrm{mK}\right),\left(0.24 \mathrm{gr} / \mathrm{cm}^{3} ; 0.5085\right.$ $\mathrm{W} / \mathrm{mK}),\left(0.26 \mathrm{gr} / \mathrm{cm}^{3} ; 0.6544 \mathrm{~W} / \mathrm{mK}\right)$. The best composite in terms of density and thermal conductivity is Specimen 2 with 4: 4: 1 composition (coconut coir: Palm Fibers: polyurethane glue).

4.2 The lowest measured temperature on the base of the coolbox is insulated composite coco fiber and fiber fibers of $0.5^{\circ} \mathrm{C}$. While the lowest temperature and the longest duration on the base coolbox insulated coconut coir composite and Palm Fiber of $0.9^{\circ} \mathrm{C}$ with a duration of 30 minutes. For the lowest temperature and the longest duration measured on the body of coolbox fish insulated composite coconut coir and Palm Fiber of $0.7^{\circ} \mathrm{C}$. The lowest measured temperatures in free air in the coolbox are insulated composite coconut coir and Palm Fibers $18.9^{\circ} \mathrm{C}$. Coolbox is able to maintain temperatures not exceeding $20^{\circ} \mathrm{C}$ until data retrieval to 34 , or 16 hours 30 minutes from the start of the test.

4.3 Based on the comparison of temperature, it can be seen that with the same treatment of coolbox, the insulation of coconut coir and Palm Fibers composite can maintain fish temperature 30 minutes longer compared to the resistance of styrofoam insulation.

As for some suggestions to be done so that the study is better, are :

a. Coconut coir and Palm Fiber used as coolbox insulation are still arranged in random form and the mixture still less evenly distributed. For further research can be developed by using fiber webbing and using fiber arrangement in a neat and patterned.

b. Testing are using a simple test tool that is not intended for scientific testing. For further tests can be done specimen test and coolbox test using special test equipment.

c. The use of outer framework of plywood-based box as coconut coir and Palm Fiber composite container resulted in less than perfect test because it does not take into account the effect of giving plywood layer and resin in making coolbox. For further research can be developed by conducting composite-making trials with other methods that can provide more complete insulation research results.

d. Insulation testing is still limited to coconut coir and Palm Fiber and does not use other parts of coconut or palm tree fiber (Arenga pinnata). For further study can be developed by using variations of other mixtures or using variations of other ingredients from both types of plants.

e. This study does not include economic analysis and coolbox resistance to environmental influences so that it can still be developed by examining both fields.

\section{REFERENCES}

[1] Afrianto, I. E., \& Liviawaty, I. E. (1989). Pengawetan dan Pengolahan Ikan. Yogyakarta: Kanisius.

[2] Alberto, D., Burmawi, \& Suryadimal. (2015). Analisa Konduktivitas Thermal Material Komposit Serat Sabut Kelapa Dengan Perlakuan Alkali Dan Resin Poliester. ejurnal.bunghatta.ac.id, Vol 6, No.2.

[3] Amiruddin, W., Iskandar, B. H., Murdiyanto, B., \& Baskoro, M. S. (2014). Efisiensi Perubahan Kerapatan Material Polyurethane Terhadap Laju penetrasi Panas Pada Palka Kapal Ikan Tradisional. KAPAL, (11) 93-98.

[4] Ayodhyoa, A. (1979). Fishing Methode. Bogor: Fakultas Perikanan Institut Pertanian Bogor.

[5] Azis, M. A., Iskandar, B. H., \& Novita, Y. (2017). Kajian Desain Kapal Purse Seine Tradisional Di Kabupaten Pinrang (Study Kasus KM. Cahaya Arafah). Albacore, 069-076.

[6] Bakri. (2010). Penentuan Sifat Mekanis Serat Sabut Kelapa Mekanikal, 23-29.

[7] Bakri. (2011). Tinjauan Aplikasi Serat Sabut Kelapa Sebagai Penguat Material Komposit. Mekanikal, 10-15.

[8] Cowd, M. (1991). Kimia Polimer. Bandung: ITB

[9] Gultom, F. (2015). Preparation and Characterization of Polyol Natural Rubber Latex Based Polyurethane Foam. Jurnal Ilmu Pertanian "Agrium", 19(2).

[10]Hidayat, M. (2017). Pemanfaatan Limbah Serbuk Kayu Sebagai Campuran Polyurethane Pada Insulasi palka kapal Ikan Tradisional. Surabaya: ITS.

[11]Holman, J. (2010). Heat Transfer Tenth Edition. New York: McGraw-Hill Companies.

[12]Ilyas, S. (1983). Teknologi Refrigerasi Hasil Perikanan. Jilid I Teknik Pendinginan Ikan. Jakarta: CV.Paripurna.

[13]Incropera, F. P., Dewitt, D. P., Bergman, T. L., \& Lavine, A. S. (2007). Fundamentals of Heat and Mass Transfer Sixth Edition. Hoboken: John Wiley \& Sons, Inc. 
International Journal of Marine Engineering Innovation and Research, Vol. 3(1), Des. 2018. 018-026 (pISSN: 2541-5972, eISSN: 2548-1479)

[14]Ishak, M., Sapuan, S., Leman, Z., Rahman, M., Anwar, U., \& Siregar, J. (2013). Sugar palm (Arenga pinnata) : Its fibres, polymers and composites. Carbohydrate Polymers, 699-710.

[15]Khedari, J., Nankongnab, N., Hirunlabh, J., \& Teekasap, S. (2004). New Low-Cost Insulation Particleboards From Mixture of Durian Peel and Coconut Coir. Building and Environment 39, 59-65.

[16]Kreith, F., Manglik, R. M., \& Bohn, M. S. (2011). Principles of Heat Transfer Seventh Edition. Stamford: Cengage Learning Inc.

[17]Masturi, Mikrajuddin, \& Khairurrijal. (2010). Efektivitas Polyvinyl Acetate (PVAc) Sebagai Matriks Pada Komposit Sampah. Berkala Fisika, (13) 61-66

[18]Mulyatno, I. P., Jatmiko, S., \& Susilo, F. (2012). Analisa Investasi kapal ikan Tradisional Purseiner 30 GT. Kapal 9, No.2, 58-67.

[19]Nasution, P., Fitri, S. P., \& Semin. (2014). Karakteristik Termofisik Komposit Sabut Kelapa Sebagai Insulator Pada Palka Ikan. Berkala Perikanan TerubukVol 42. No.2, 82-92.

[20]Nasution, P., P.Fitri, S., \& Semin. (2014). Karakteristik Fisik Komposit Sabut Kelapa Sebagai Insulator Palka Ikan. Berkala Perikanan Terubuk, (42) 82-92.

[21]Prado, J., \& Dremiere, P. (1991). Petunjuk Praktis Bagi Nelayan. Semarang: Balai Pengembangan Penangkapan Ikan.

[22]Prasetyono, A. P. (2016, July 10). Kolom Opini: Ikan Melimpah di Laut, Kemana Nelayan Kita? Retrieved from ristekdikti.go.id: https://ristekdikti.go.id/ikan-melimpah-di-laut-kemana-nelayankita/

[23]Purnama, E., Djoko, H. D., \& Masruroh. (2010). Studi Pengaruh Penambahan PVAc (Polyvinyl Acetate) dan Ukuran Butir Terhadap Kuat Tekan Bahan Target Karbon untuk Deposisi Lapisan Tipis Diamond Like Carbon (DLC). Brawijaya Physics Student Journal, (1) 1.

[24]Sekretariat Kabinet Republik Indonesia. (2016, Maret 4). Artikel: Potensi Besar Perikanan Tangkap Indonesia. Retrieved from
Sekretariat Kabinet Republik Indonesia Web site: http://setkab.go.id/potensi-besar-perikanan-tangkap-indonesia/

[25]Sitakar, N. M., Nurliana, Jamin, F., Abrar, M., Manaf, Z. H., \& Sugito. (2015). PENGARUH SUHU PEMELIHARAAN DAN MASA SIMPAN DAGING IKAN NILA (Oreochomis niloticus) PADA PENYIMPANAN SUHU -20'C TERHADAP JUMLAH TOTAL BAKTERI. Medika Veterinaria, 162-165.

[26]Sondana, A. (2013). Desain Sistem Pendingin Ruang Muat Kapa Ikan tradisional Dengan Teknologi Insulasi Vakum. Teknik Sistem Perkapalan Vol 1, No.1, 1-5.

[27]Susanti, M. T., \& Purba, P. (2008). Rancang Bangun Kotak Penyimpan Ikan Berinsulasi Untuk Mempertahankan KUalitas Ikan Dengan Proses Pendinginan Serta Aplikasinya Pada Ikan Tongkol (Auxis Thazard). Teknik,29 (2), 143-147.

[28]Taj, S., Munawar, M., \& Khan, S. (2007). Natural FiberReinforced Polymer Composites. Proceedings-Pakistan Academy of Sciences 44(2), 129.

[29]Yunita, Idris, N., \& Abdullah. (2012). Thermal Conductivity of Foamed Concrete Fibre Arenga Pinnata Merr. The Aceh Physica Society, Vol 1, No. 1, 13-14.

[30] EM Wardhana, T Pitana, \& I Suryanto. (2016). Carbon Footprint Estimation for Pole and Line Fishing Vessel According to Its Operation Mode -Study Case at Papua Fisheries, Journal of Ocean, Mechanical and Aerospace -Science and Engineering- 30, 20

[31] T. F. Nugroho, W. Busse, E. M. Wardhana, and J. I. O Panggabean, "Heat Transfer Analysis of Thermal Oil Plant on Fuel Oil Tanks of 17500 LTDW Product Oil Tanker,' International Journal of Marine Engineering Innovation and Research., vol. 2, no. 2, Mar. 2018. 